Ali Noruzy,

PhD Candidate in Educational Administration of the Department of Educational Administration, University of Tehran (Tehran, Iran)

Khodayar Abili,

PhD in Higher Education Administration, Full Professor of the Department of Educational Administration, University of Tehran (Tehran, Iran);

Javad Pourkarimi,

PhD in Educational Administration, Assistant Professor of the Department of Educational Administration, University of Tehran (Tehran, Iran);

Manouchehr Ansari,

PhD in Management Science, Associate Professor of the Department of MBA, University of Tehran (Tehran, Iran)

\title{
A CONCEPTUAL MODEL FOR SERVICE INNOVATION EXCELLENCE FOR NON-GOVERNMENTAL HIGHER EDUCATION
}

Using a qualitative method, this study developed a model for service innovation excellence for nongovernmental higher education. Analysis of qualitative data showed that five major themes including innovation leadership, innovation strategies, innovation process, innovation resources, competencies and capabilities of faculty members form innovation excellence of non-governmental higher education. The most important strategies identified for achieving innovation in higher education institutions included innovation creation, benchmarking, expert recruitment, and joint venture and innovation absorption. In addition, task competency, learning ability, research skills, innovation intention, information literacy, creative thinking and teamwork skills are the most important competencies and capabilities identified for realization of innovation in higher education institutions.

Keywords: innovation, services, excellence model, higher education, model.

DOI: 10.21272/mmi.2017.2-12

Introduction. Despite growth and development of service sector in economies of developed countries, service innovation has been less taken into consideration [1]. Observations and studies show that many service organizations of developing countries are not innovative and creative; they fail in adaption with developments and changes of the present era and they are often run by traditionally ineffective methods. Innovation is required for continuity and survival of service organizations in competitive world and domestic and international complex markets. Under these conditions, service organizations will certainly fail if they do not consider innovation seriously, because environmental changes and customer demands are so diverse that inactive and non-innovative organizations will quickly lose the competition. Meanwhile, educational institutions as one of the most critical service organizations are forced to meet the requirements of customer-orientation, respond to customer needs and ultimately commit to adopt innovative approaches in order to survive in the competitive era [2, 3]. Although innovation intention was not taken seriously in management of these institutions due to the slow flow of competition, the role of innovation is currently highlighted in attracting new customers and retaining the current customers due to the increasing number of institutions providing educational services and raising expectations of customers and complexity of their choices $[4,5]$. Other concerns of higher education institutions are survival in the competition, branding and good ranking compared to other competitors [6]. Due to the massive growth of these institutions, applicants have numerous alternatives to choose their favorite institution. In other words, institutions do not choose their applicants, but the applicants decide to choose them [5]. According to Leadbeater [7] higher education institutions have no choice but using overreaction procedures or adopting innovative approaches due to the 
numerous expectations of applicants, the challenges of survival in the competition and coping with current turbulent and changeable environment. This situation requires a paradigm shift from traditional management practices to adoption of new methods, processes and technologies. Under these conditions, educational institutions enter the business world. The competitive advantage gained through innovation is one of the main strategies of these institutions [8]. In Iran, the sharp decline in the number of students and applicants of non-governmental institutions due to the reducing rate of population in future is the main concern of investors and managers of these institutions. This problem has been associated with shutdown of some non-governmental academies. Over time, this problem will further lead to the shutdown of many non-governmental institutions. In recent years, foundation of nongovernmental higher education institutions which had grown by population growth has been reduced; to attract applicants, current institutions must focus on their innovative services in order to survive and subsequently surpass their competitors. These institutions will require different, up to date services which are adapted to changing needs of applicants. This will not be feasible except by using innovative processes to convert threats into opportunities. However, non-governmental higher education institutions are less inclined to innovate in the provision of educational services; the innovations made by these institutions result from random processes rather than strategic and systematic processes. Clearly, many of these educational institutions lack a systematic framework which allows them to manage changes effectively, encourage innovation and achieve positive outcomes. Non-governmental higher education institutions should review their traditional service providing processes and use innovative ideas, processes and techniques to survive in future competition. In fact, continuation of current trend in educational services and adherence to traditional processes may lead to their survival in current conditions; however, it will be followed by their shutdown due to the reduced number of higher education applicants, more competitive absorption process and centrality of applicant needs and expectations in higher education services. Therefore, non-governmental higher education institutions will require model for survival and, beyond that, competitive advantage gained through innovation in services. Accordingly, the purpose of this study is to identify the factors of service innovation excellence in non-governmental higher education institutions and develop its model for these institutions.

Theoretical background. Service innovation is a new service or renovation of an existing service which can gain profit for the organization; this profit usually results from the added value provided by renovation for customers. Service innovation refers to development of new practical ideas to improve efficiency and effectiveness of services [9]. To consider renovation as an innovative event, it should be seemed new and modern in a broader sense; it should involve elements which can be repeated in new situations, that is, it should provide generalizable aspects and attributes. Service innovation process refers to a process through which the explained renovations are realized [10]. Service innovation refers to exclusive search, development and marketing of new arrangement of products and practices which provide new service experiences in order to meet unseen and seen customer needs. Service innovation refers to development of new practical ideas to improve efficiency and effectiveness of service [9]. In summary, it seems that service innovation process is a process through which renovations are realized [10]. This process has a multidisciplinary nature, since various stakeholders are involved in developing the concept of service system and implementing the system. The real outcome of this may be a combination of existing elements or completely new presentations [11]. Finally, the ultimate goal is to meet customer needs through a valuable, high quality method.

Evaluating 182 American service organizations, Froehle et al [12] considered team building, standard processes defined for development of new services, and information technology as three important factors in promotion of new service development.

Based on his evaluations of organizations, Tsou [13] concluded that a multistep process is required for service innovation excellence. In his model, innovation performance is considered as the first step. 
Innovation strategies are extracted from this current performance of the organization for future reference. Business intelligence as one of the key factors of organization leads to innovative service management and technology management. Management ideas, resources and competencies of human resources can also facilitate development of innovation. In the final step, application of innovations is evaluated. Den Hertog [14] considered the in-depth understanding of customer needs and systematic study of technological advances, conceptualization of the ideas provided for formulation of ideas, severability and composition of current services, cooperation with other organizations to produce and implement new innovations, standardization of the developed innovations, and organizational learning as the most important factors of organizational dynamism for innovation management of service organizations. In his model, Tsou [13] highlighted the role of identification and attraction of environmental knowledge (absorptive capacity), knowledge sharing with other organizations (coordination capacity), establishment and strengthening of relationships with other organizations (relational capability) as well as processes and formal structures used in capture, analysis and sharing of knowledge absorbed within the organization in development of electronic innovations of service institutions. Park and Dahlgaard [15] developed a model to determine the formation of service innovation excellence by eight interacting components. In this model, leadership plays an important role in innovation intention and customer orientation; moreover, personnel, collaboration, resources, strategies and plans help innovative processes in the organization. Personnel, innovation processes and innovation outcomes also play a determining role in formation of innovative outcomes. Lin [16] first evaluates customer characteristics such as expectations, cognitive characteristics, skills and capabilities. These evaluations are explored by using information technology which can help providing new services. Considering organizational capabilities and human resources, these evaluations lead to new service providing system. In this model, new customers, new services and new service providing system form main dimensions of service innovation.

Dervitsiotis [17] developed a framework for evaluation of organizational innovation excellence. His framework involved innovative strategy, collaboration of employees, innovation resources, customer feedback, collaboration of suppliers and innovation processes. However, his framework is only applicable for manufacturing companies.

Using previous models such as EFQM and Baldrige, Asif and Gouthier [18] developed a model for service excellence. This model is in fact an integration of previously known models which have been only used for improving services, while services and its excellence require their own peculiarities. No new step can be taken to improve theoretical literature only by relying on organizational excellence models. In other words, components of their model included leadership, customer orientation, plans and strategies, participations and resources and outcomes of innovation. This model is different from previous models in that the model is experimentally confirmed using path analysis and its fit is supported.

Methodology. The purpose of this study is to identify components of service innovation excellence and show their relationships. As no other study has been conducted in this area, a qualitative study is required for careful evaluation of indicators of innovation excellence in educational services. In qualitative approach, people, their perceptions, meanings, and recognition are considered as the primary source of data. Since the focus of this study is the perceptions, meanings, and recognition of interviewees regarding innovation excellence in educational services, this study also uses a qualitative approach. In this type of research, interview is an acceptable technique for discovering, understanding and recognition of an individual or a group of people [19]. Using semi-structured interviews with experts, this study attempts to identify indicators of innovation excellence in educational services. In this regard, theoretical background is determined by reviewing literature and the collected qualitative data is used to identify components of service innovation excellence through semi-structured interviews.

Population and sampling. In the qualitative phase, the studied population included academic 
experts identified by using purposive sampling. In fact, the focus of this study was on people with higher knowledge on the subject and practical and research experience regarding innovation in educational services. Based on snowball sampling used in qualitative research, interviewees were asked to introduce other experts in this field. Experts were interviewed in two groups, academic experts and managers of non-government educational institutions. Inclusion criteria included:

1) Research experience in the field of innovation

2) Creation or launch of new services in a non-governmental university

3) Successful foundation of non-governmental university

In qualitative phase, sample size was determined based on theoretical saturation; that is, interviews were continued until more interviews led to newer data and greater understanding of indicators of service innovation excellence to develop the model. Interviews were terminated when more interviews did not lead to more data and previous data was repeated [20,21]. With this process, 15 experts were determined sufficient for interviews. Characteristics of the experts are listed in Table 1.Before interviews, a summary of the research design, results of literature review as well as objectives and questions were sent via email to interviewees for previous study. At the beginning of interviews, the procedures were briefly explained. Then, questions were asked.

Table 1 - General characteristics of the interviewees in the qualitative phase

\begin{tabular}{|c|l|c|}
\hline & Interviewee code & Organizational position \\
\hline 1 & Interview1 & Faculty member \\
\hline 2 & Interview2 & Faculty member \\
\hline 3 & Interview3 & Head of department \\
\hline 4 & Interview4 & Faculty member \\
\hline 5 & Interview5 & Vice president and deputy of a higher education institution (non-governmental) \\
\hline 6 & Interview6 & Founder member of a higher education institution (non-governmental) \\
\hline 7 & Interview7 & Hember of board of directors and faculty member \\
\hline 8 & Interview8 & Faculty member \\
\hline 9 & Interview9 & Fad of department \\
\hline 10 & Interview10 & Depulty member \\
\hline 11 & Interview11 & Member of the Board of Trustees and faculty member \\
\hline 12 & Interview12 & Faculty member \\
\hline 13 & Interview13 & Faculty member \\
\hline 14 & Interview14 & Minemer \\
\hline 15 & Interview15 &
\end{tabular}

Data collection. In the qualitative phase, data was collected by interview as a key element of qualitative research. In the present study, semi-structured interviews were performed with academic experts to identify innovation excellence in educational services. Semi-structured interviews were used because they allow exchange of ideas and direction of interview to achieve objectives of the study. To record qualitative data and more focus of interviewer on the interview process, the interviews were all recorded by Dictaphone with the permission of interviewees; moreover, notes were taken from key points of each interview. The main topics raised in the interview process were as follows:

1. What are characteristics and skills of manager or leader to launch and provide innovative services in non-governmental educational institutions?

2. What are the strategies used by non-governmental higher education institutions for achieving innovation excellence?

3. What are the characteristics and competencies of employees (faculty members and experts) in launching and providing innovative services in non-governmental educational institutions?

4. What are the processes or steps used to realize service innovation in a non-governmental 
educational institution?

5. What are the resources used to realize service innovation in non-governmental educational institutions?

Interviews were transcribed verbatim and data was analyzed based on responses of participants to each question. The researcher primarily coded the data and extracted numerous codes. Then, the extracted codes were classified and each class fell in one theme. Inter-coder reliability was used to determine dependability or consistency; the results indicate dependability or consistency.

Research procedure. Theoretical background related to research in the areas of innovation, innovation excellence, educational services, innovation in educational services and service innovation excellence in educational institutions was examined in the first phase of pilot study. At this phase, literature was reviewed; the primary model was developed and provided to experts. Qualitative interviews were performed; data was collected by targeted selection of experts and managers of nongovernmental educational institutions. Once data was collected, interviews were transcribed verbatim and analyzed. Primary and secondary coding were performed; finally, themes were identified (Figure 1). Using the extracted themes, the conceptual model was developed.

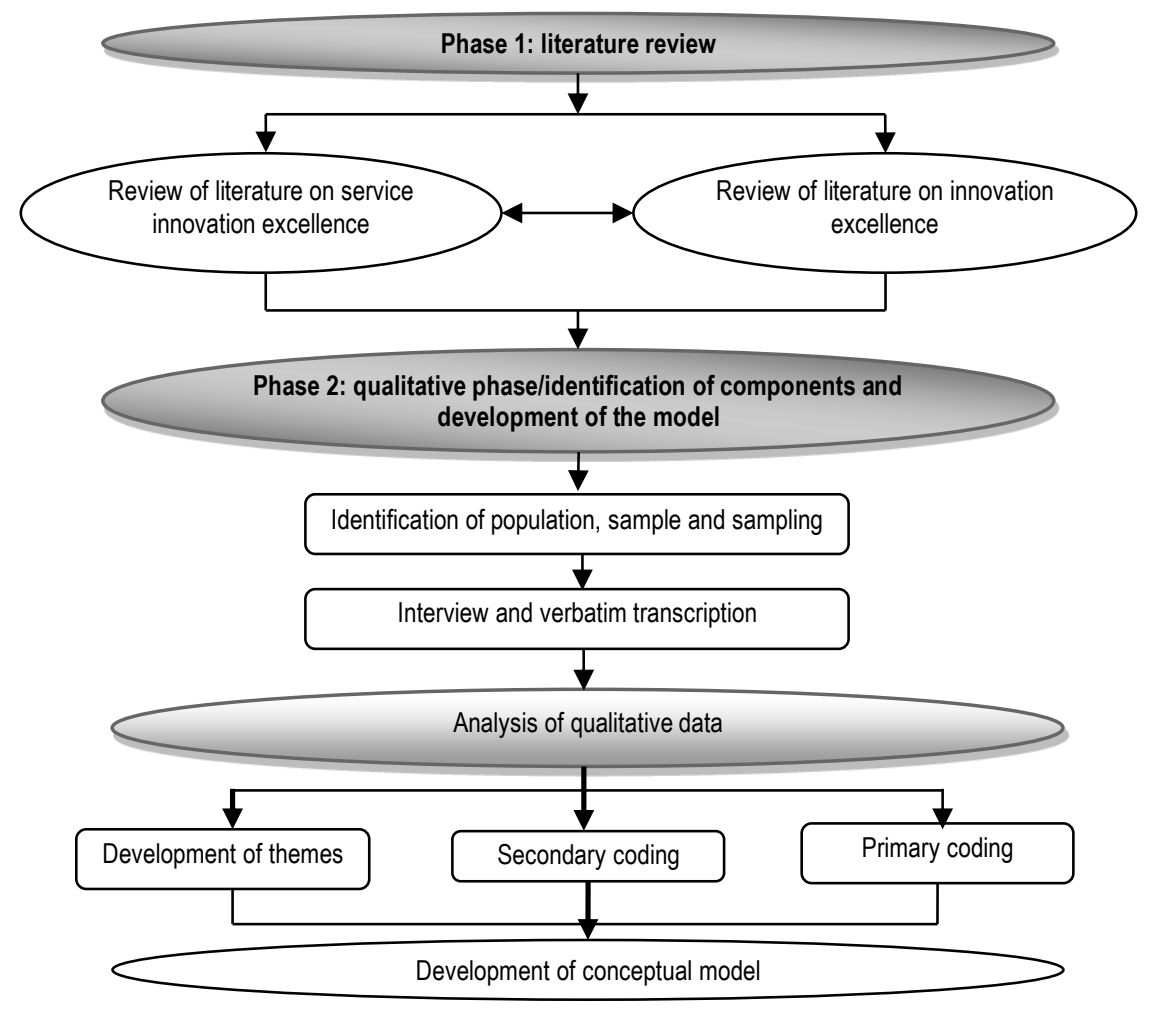

Figure 1 - Methods and phases of the study

Results. All findings related to five questions were classified after initial coding and main themes were extracted. Findings related to each question are listed in the table. The first question measures competencies and characteristics of leadership for achieving innovation excellence. As shown in Table 
А. Норузі, Х. Абілі, Д. Пуркарімі, М. Ансарі. Концептуальна модель інноваційного удосконалення сфери послуг для неурядової вищої освіти

2, numerous characteristics and competencies were considered for leadership of non-governmental institutions. To determine adequate frequency for selection of the main theme, minimum frequency was set to 5 ; the reason is that the adequate frequency of 5 or at least one-third of interviewees mentioning a theme is required for selection of that theme. This limit shows whether an extracted theme is selected for inclusion in the model. Results showed that 6 main themes can be extracted primarily for competencies and characteristics of leadership for innovation excellence. As shown in Table 2, the most important competencies and characteristics include innovation vision, professional competencies, innovation culture, motivation, commitment to innovation and market orientation. Frequency of these themes was higher than 5 . However, frequency of customer orientation was lower than 5; therefore, it was not considered as the main theme.

Table 2 - Competencies and characteristics of leadership for realization of innovation excellence

\begin{tabular}{|c|c|c|c|}
\hline Codes (identified concepts) & Theme & Experts & Frequency \\
\hline $\begin{array}{l}\text { Relationship with industry needs, adaption to society needs, attention to market needs, market } \\
\text { understanding, market analysis, market dominance, competitor monitoring, identification of new } \\
\text { needs of market, service in the fields with competitive advantage, market research, market } \\
\text { monitoring, labor market requirement, attention to competitive market, good relationship with industry, } \\
\text { good relationship with academic requirements, correct understanding of competitors, market condition } \\
\text { monitoring, detailed market analysis, market information capture, identification of real society needs, } \\
\text { good relationships with society needs, market orientation, linking industry with universities }\end{array}$ & $\begin{array}{c}\text { Market } \\
\text { orientation }\end{array}$ & $\begin{array}{c}\text { M1, M5, M6, } \\
\text { M7, M8, M9, } \\
\text { M10, M12, } \\
\text { M13 }\end{array}$ & 9 \\
\hline $\begin{array}{l}\text { Acceptance and implementation of new ideas, application of ideas in decisions, processes and } \\
\text { structure, experience of new process or ideas, application of experiences of top universities, risk- } \\
\text { taking, utilization of experiences of universities, valuation of innovation, innovation acceptance, } \\
\text { openness to innovative ideas }\end{array}$ & $\begin{array}{l}\text { Commitment } \\
\text { to innovation }\end{array}$ & $\begin{array}{l}\mathrm{M} 2, \mathrm{M} 4, \mathrm{M} 6 \\
\mathrm{M} 11, \mathrm{M} 12 \\
\mathrm{M} 13, \mathrm{M} 15\end{array}$ & 8 \\
\hline $\begin{array}{l}\text { Open atmosphere and culture, organizational environment for innovation, innovation as a value, } \\
\text { environment for innovation, right culture and environment for innovation, trust between members, } \\
\text { institutional culture of innovation, innovation encouraging culture, innovation acceptance environment, } \\
\text { trial and error acceptance, open environment for students and faculty members, necessary conditions } \\
\text { for creative ideas }\end{array}$ & $\begin{array}{l}\text { Innovation } \\
\text { culture } \\
\text { creation }\end{array}$ & $\begin{array}{r}\mathrm{M} 1, \mathrm{M} 2, \mathrm{M} 4 \\
\mathrm{M} 9, \mathrm{M} 11 \\
\mathrm{M} 13, \mathrm{M} 15\end{array}$ & 7 \\
\hline $\begin{array}{l}\text { Motivation for innovation, encouragement, innovation motives, rewarding for innovation, motivation, } \\
\text { importance of innovative ideas, support for innovative ideas, support for innovation, incitement to } \\
\text { change, encouragement of new ideas, employment of ideas, encouragement of innovation, } \\
\text { encouragement of innovative people, stimulation of members for innovation, stimulation for innovation } \\
\text { and creativity, appreciation of members }\end{array}$ & Motivation & $\begin{array}{c}\mathrm{M} 2, \mathrm{M} 3, \mathrm{M} 9 \\
\mathrm{M} 11, \mathrm{M} 13 \\
\mathrm{M} 15\end{array}$ & 6 \\
\hline $\begin{array}{l}\text { Strategic vision, futurist perspective, ambitious vision, shared vision, foresight, strategy orientation, } \\
\text { transformation perspective }\end{array}$ & $\begin{array}{l}\text { Innovation } \\
\text { vision }\end{array}$ & $\begin{array}{c}\mathrm{M} 1, \mathrm{M} 2, \mathrm{M} 3 \\
\mathrm{M} 9, \mathrm{M} 12 \\
\end{array}$ & 5 \\
\hline $\begin{array}{l}\text { Professional competencies of management, academic expertise, managerial experience, academic } \\
\text { base, educational background, scientific background, specializing in educational management, } \\
\text { familiarity with peculiarities of educational institutions, correct understanding of nature of educational } \\
\text { institutions, relevant expertise, specialized competence, ability to weigh and assess advantages and } \\
\text { disadvantages of innovations, dominance on educational market, specializing in management, correct } \\
\text { understanding of higher education environment, correct understanding of marketization of higher } \\
\text { education }\end{array}$ & $\begin{array}{c}\text { Professional } \\
\text { competencie } \\
\mathrm{S}\end{array}$ & $\begin{array}{l}\mathrm{M} 1, \mathrm{M} 4 \\
\mathrm{M} 12, \mathrm{M} 13 \\
\mathrm{M} 15\end{array}$ & 5 \\
\hline Satisfaction of stakeholders, a good relationship with student needs, satisfaction of freshman & $\begin{array}{l}\text { Customer } \\
\text { orientation }\end{array}$ & $\begin{array}{l}\text { M1, M4, } \\
\text { M13 }\end{array}$ & 3 \\
\hline
\end{tabular}

The second question measured strategies for achieving innovation in services provided by nongovernmental institutions. This question was asked in a semi-structured form. Through the interview, experts pointed to a wide range of components. Table 3 shows that 5 themes can be extracted for innovation strategy for non-governmental higher education institutions. According to Table 6 , the most important strategies identified for realization of innovation in higher education institutions include innovation creation, benchmarking, expert recruitment, joint venture and innovation absorption. Frequency of these themes was higher than 5 . 
Table 3 - Identified innovation strategies

\begin{tabular}{|c|c|c|c|}
\hline Codes (identified concepts) & Theme & Experts & Frequency \\
\hline $\begin{array}{l}\text { Attract ideas of students, use customer knowledge, use knowledge of students and industry and other } \\
\text { stakeholders, analyze opportunities and threats, provide a survey system for getting ideas, consider } \\
\text { customer feedback, employ ideas for innovation, gain creative ideas, gain innovative ideas of students } \\
\text { using scientific communities of students, use ideas of practitioners of industry and services, hold } \\
\text { meetings with entrepreneurs and policymakers and employers of labor market, found forums for survey, } \\
\text { invite experts of other fields, invite industry experts, attract innovative actions }\end{array}$ & \begin{tabular}{l|} 
Innovation \\
absorption
\end{tabular} & \begin{tabular}{|}
$\mathrm{M} 1, \mathrm{M} 2, \mathrm{M3}$ \\
$\mathrm{M} 4, \mathrm{M} 5, \mathrm{M6}$ \\
$\mathrm{M} 8, \mathrm{M} 9$ \\
$\mathrm{M} 10, \mathrm{M} 11$ \\
$\mathrm{M} 12, \mathrm{M} 13$ \\
$\mathrm{M} 15$
\end{tabular} & 13 \\
\hline $\begin{array}{l}\text { Create new product ideas, hold brainstorming sessions, analyze strengths and weaknesses, research } \\
\text { on innovative ideas obtained from inside or outside, work on new ideas, create innovative process, } \\
\text { create innovative ideas within the organization, obtain ideas from internal members, hold focus group } \\
\text { meetings, attract teachers to use their ideas in education services, hold brainstorming sessions, hold } \\
\text { conference sessions, consider research strategy followed by production, hold consultation meetings, } \\
\text { research, research on ideas, extract innovative designs, ideation, support research and academic } \\
\text { innovation, form think tanks, stimulate innovation, form design groups for new processes, teach } \\
\text { innovation creation to members. }\end{array}$ & $\begin{array}{c}\text { Innovation } \\
\text { creation }\end{array}$ & $\begin{array}{c}\text { M1, M2, M3, } \\
\text { M4, M5, M9, } \\
\text { M11, M12, } \\
\text { M13, M14, } \\
\text { M15 }\end{array}$ & 11 \\
\hline $\begin{array}{l}\text { Attract experts, attract creative people, attract innovative faculty members, attract innovative faculty } \\
\text { members, use creative educational experts, recruit innovative employees, recruit creative employees, } \\
\text { attract talented personnel in all levels, recruit elite faculty members, attract knowledge of stakeholders, } \\
\text { recruit talented people and good teachers, recruit expert professors, recruit qualified educational experts, } \\
\text { recruit innovation consultants, hire competent experts, use active and elite professors and students, } \\
\text { employ creative and innovative people }\end{array}$ & $\begin{array}{c}\text { Expert } \\
\text { recruitment }\end{array}$ & $\begin{array}{c}\text { M1, M2, M3, } \\
\text { M4, M5, M6, } \\
\text { M7, M11, } \\
\text { M12, M14, } \\
\text { M15 }\end{array}$ & 11 \\
\hline $\begin{array}{l}\text { Use innovations of top universities, employ successful experience of other universities, use } \\
\text { experience of top universities, follow universities with top rankings, identify standard services of other } \\
\text { universities, localize and normalize innovations of foreign universities, extract best practices of top } \\
\text { universities, use innovative experiences of other universities, follow other universities, use valuable } \\
\text { experiences and innovative designs of top universities, idealize successes, adopt ideas, analyze } \\
\text { performance of leading universities, scan innovative process of other universities, find new } \\
\text { innovations in research and teaching process of universities, identify and analyze innovative actions } \\
\text { of other universities, localize innovative designs of successful universities and higher education } \\
\text { institutions }\end{array}$ & $\begin{array}{l}\text { Bench- } \\
\text { marking }\end{array}$ & $\begin{array}{c}\text { M1, M6, M8, } \\
\text { M9, M10, } \\
\text { M13, M14, } \\
\text { M15 }\end{array}$ & 8 \\
\hline $\begin{array}{l}\text { Attract participation of innovative people, take advantage of creative people, invite experts to meetings, } \\
\text { consult and cooperate with outsider experts, attract creative forces, cooperate with innovation and } \\
\text { development experts, invite outsider experts for participation, collaborate with other academic experts, } \\
\text { employ collaboration and consultation with a specific group, collaborate with service experts }\end{array}$ & $\begin{array}{c}\text { Joint } \\
\text { venture }\end{array}$ & $\begin{array}{l}\mathrm{M} 1, \mathrm{M} 2, \mathrm{M6} \\
\mathrm{M} 11, \mathrm{M} 12 \\
\mathrm{M} 15\end{array}$ & 6 \\
\hline
\end{tabular}

The third question examined competencies and characteristics of faculty members and employees. This question was asked from 15 experts. Table 4 lists the interviews and identified codes. Results showed that 5 themes can be extracted for competencies and capabilities of employees for innovation in non-government higher education institutions. As shown in Table 4,task competency, learning ability, research skills, innovation intention, information literacy, creative thinking and teamwork are the most important competencies and capabilities identified for implementation of innovation in higher education institutions, because their frequency was higher than 5 . However, student-orientation was discarded due to its lower frequency.

\section{Table 4 - The themes identified for competencies and characteristics of employees}

\begin{tabular}{|c|c|c|c|}
\hline Codes (identified concepts) & Theme & Experts & Frequency \\
\hline $\begin{array}{l}\text { Able to use IT, have computer skills, have information literacy, use digital tools, able to use new } \\
\text { technologies, take advantage of information resources, have computer skills, use digital tools, have } \\
\text { computer skills, have media literacy, use electronic devices, have digital skills, have media skills, have high } \\
\text { information literacy, use internet, use upgraded digital devices, use ITC, upgrade capabilities of new } \\
\text { technologies, use social media, able to use software, able to use hardware, have software proficiency, } \\
\text { dominate on relevant technology, able to use modern devices }\end{array}$ & $\begin{array}{c}\text { Information } \\
\text { literacy }\end{array}$ & $\begin{array}{l}\text { M1, M2, M3, } \\
\text { M4, M5, M7, } \\
\text { M8, M9, } \\
\text { M10, M11, } \\
\text { M12, M13, } \\
\text { M14, M15 }\end{array}$ & 14 \\
\hline
\end{tabular}


Table 4 (continued)

\begin{tabular}{|c|c|c|c|}
\hline Codes (identified concepts) & Theme & Experts & Frequency \\
\hline $\begin{array}{l}\text { Have problem-solving skills, able to analyze, able to analysis and research, have research skills, have } \\
\text { research responsibility, collaborate with strong researchers, able to analyze problems, solve problems with } \\
\text { problem solving techniques, be aware about research methods, analyze problems, seek and develop } \\
\text { solutions and ideas, analyze problems, be curious about problems, dominate on research skills, have } \\
\text { problem-solving skills, acquire problem-oriented approach, solve problems, be research oriented, have } \\
\text { research skills }\end{array}$ & $\begin{array}{l}\text { Research } \\
\text { skills }\end{array}$ & $\begin{array}{l}\text { M1, M2, M4, } \\
\text { M7, M8, M9, } \\
\text { M10, M11, } \\
\text { M13, M14 }\end{array}$ & 10 \\
\hline $\begin{array}{l}\text { Have willingness to innovate, present different solutions, tend to use creative methods, have innovation } \\
\text { intention, accept change, tend to change, tend to present new solutions, tend to change and innovate, have } \\
\text { motivation and innovation intention, have tendency for innovation, do not resist to change, expect innovation } \\
\text { and creativity, motivate innovation, have creative thinking skills, have flexibility, adapt to conditions, accept } \\
\text { change, not resist to change, be pragmatic, adapt to its changing environment, bear failures, be pragmatic }\end{array}$ & $\begin{array}{l}\text { Innovation } \\
\text { intention }\end{array}$ & $\begin{array}{l}\text { M1, M2, M3, } \\
\text { M4, M5 } \\
\text { M10, M11, } \\
\text { M13, M14, } \\
\text { M15 }\end{array}$ & 10 \\
\hline $\begin{array}{l}\text { Challenge phenomena, consider deconstruction, consider modernization, challenge phenomena, be risk- } \\
\text { taking, have creative thinking skills, have new thinking, challenge existing processes, be risk-taking, } \\
\text { embrace criticism, consider self-improvement, have flexibility, have mobility, lack conservatism, have a } \\
\text { sense of challenging, bear failure, provide ideas and solutions, be pragmatic, have flexibility, do not be } \\
\text { narrow, use creative attitude, lack conservatism, have creative thinking skills, analyze problems, provide } \\
\text { new solutions, raise challenging problems in class, have creative thinking skills, have the courage to confront } \\
\text { problems, embrace criticism, evaluate self, embrace criticism, consider fair criticism, take risk as a common } \\
\text { practice among members, be risk-taking, have flexibility, have freedom of action, challenge, not being afraid } \\
\text { of failure }\end{array}$ & $\begin{array}{l}\text { Critical } \\
\text { thinking } \\
\text { skills }\end{array}$ & $\begin{array}{l}\text { M2, M3, M4, } \\
\text { M7, M10, } \\
\text { M11, M12, } \\
\text { M13, M14, } \\
\text { M15 }\end{array}$ & 10 \\
\hline $\begin{array}{l}\text { Have professional competence, dominate on areas of expertise, have specialized theoretical knowledge, } \\
\text { have intelligence and practical work experience, have expertise in academic knowledge, have specialized } \\
\text { training, have work experience related to field, have strong training skills, dominate on teaching and } \\
\text { research, have adequate expertise, manage classroom, have knowledge of English, have technical } \\
\text { capabilities, have knowledge of languages, have specialized competence in the field }\end{array}$ & $\begin{array}{c}\text { Task } \\
\text { competency }\end{array}$ & $\begin{array}{l}\text { M1, M5, M8, } \\
\text { M9, M10, } \\
\text { M12, M13, } \\
\text { M14, M15 }\end{array}$ & 9 \\
\hline $\begin{array}{l}\text { Be fluent on modern knowledge, able to absorption, able to learn, acquire knowledge, use the latest } \\
\text { scientific findings in their job, have up-to-date knowledge about career, take advantage of information } \\
\text { resources, use databases, able to acquire new knowledge by faculty members, possess new knowledge, } \\
\text { present new findings to students, have learning skills of information resources, update knowledge, able to } \\
\text { learn from experiences as well as various resources, acquire new knowledge and expertise, have learning } \\
\text { skills, have learning skills from others, able to learn CT skills }\end{array}$ & $\begin{array}{l}\text { Learning } \\
\text { ability }\end{array}$ & $\begin{array}{l}\text { M1, M2, M3, } \\
\text { M4, M5, M9, } \\
\text { M10, M11, } \\
\text { M13 }\end{array}$ & 9 \\
\hline $\begin{array}{l}\text { Have teamwork culture, share knowledge, share findings, share knowledge and findings with other people, } \\
\text { tend to have teamwork and share ideas, tend to share knowledge, tend to share knowledge, tend to } \\
\text { cooperate, tend to share new ideas, encourage teamwork }\end{array}$ & Teamwork & $\begin{array}{l}\text { M2, M3, M5, } \\
\text { M7, M8, } \\
\text { M10, M13, } \\
\text { M15 }\end{array}$ & 8 \\
\hline
\end{tabular}

The fourth question addresses the processes of innovation excellence in educational services. This question was asked in a semi-structured form. Through the interview, experts pointed to a wide range of components. Table 5 shows that 7 themes can be extracted for innovation processes in nongovernmental higher education institutions. According to this table, market evaluation, idea exploration, idea selection, innovative planning, pilot implementation, innovation commercialization and feedback are the major steps for realization of innovation in higher education institutions; frequency of these components were higher than 5 .

\section{Table 5 - The themes identified for processes of service innovation excellence}

\begin{tabular}{|c|c|c|c|}
\hline Codes (identified concepts) & Theme & Experts & Frequency \\
\hline $\begin{array}{l}\text { Specify the roles of human resources, provide necessary resources, design innovation action plan, } \\
\text { identify goals, set operational goals, set run time, set type of action, determine type of control, evaluate } \\
\text { and maintain market entry, provide resources for innovation, design implementation plan, determine } \\
\text { necessary equipment, develop executive plan, develop administrative innovation process, provide } \\
\text { conditions, prepare the environment for implementation, develop angles of implementation, determine } \\
\text { technical capabilities to launch innovative services, design innovation strategy, design innovation } \\
\text { implementation, marketing new services, provide reasonably priced services, provide services in the } \\
\text { right place }\end{array}$ & $\begin{array}{c}\text { Design of } \\
\text { innovation plan }\end{array}$ & $\begin{array}{c}\text { M1, M2, } \\
\text { M3, M4, } \\
\text { M5, M6, } \\
\text { M8, M9, } \\
\text { M10, M11, } \\
\text { M12, M13, } \\
\text { M14, M15 }\end{array}$ & 14 \\
\hline
\end{tabular}


Table 5 (continued)

\begin{tabular}{|c|c|c|c|}
\hline Codes (identified concepts) & Theme & Experts & Frequency \\
\hline $\begin{array}{l}\text { Identify expectations of employers, identify needs and expectations of students and employers, } \\
\text { monitor competitors, identify level of innovation and change, survey, specify area of innovation, } \\
\text { understand current situation of services, understand market, evaluate market, understand nature } \\
\text { and current level of educational services, marketing mechanisms, follow market, proceed based } \\
\text { on supply and demand, determine the innovations used, extract ideas, extract valuable ideas, } \\
\text { identify ideas which contribute to success of university, discover ideas which attract customer } \\
\text { satisfaction, identify applicable ideas, consider competitors, identify market structure, analyze } \\
\text { market, identify new service market, identify changing needs of the higher education market, } \\
\text { identify the type of innovative services }\end{array}$ & Market evaluation & $\begin{array}{l}\text { M1, M2, } \\
\text { M5, M6, } \\
\text { M8, M9, } \\
\text { M10, M11, } \\
\text { M12, M13, } \\
\text { M14, M15 }\end{array}$ & 12 \\
\hline $\begin{array}{l}\text { Consider feedbacks to improve ideas, survey to identify weaknesses, improve, innovation } \\
\text { continuous, acquiring feedback from stakeholders, determine how to control innovation, monitor } \\
\text { innovation, report for more effective innovation, get feedback, consider corrective actions, obtain } \\
\text { feedback from students and other users of innovative services, reform innovation in dealing with } \\
\text { problems, survey, alleviate problems, implement innovation in a cross-sectional pilot way, } \\
\text { consider pilot implementation of innovation, monitor innovation }\end{array}$ & Feedback & $\begin{array}{l}\text { M1, M2, } \\
\text { M3, M4, } \\
\text { M5, M8, } \\
\text { M9, M10, } \\
\text { M13, M14, } \\
\text { M15 } \\
\end{array}$ & 11 \\
\hline $\begin{array}{l}\text { Discover new ideas, absorb ideas from inside or outside, gather innovative ideas, gather new } \\
\text { thoughts and ideas, generate ideas, generate ideas logically and systematically, get ideas, obtain } \\
\text { innovative thinking, provide innovative solutions, provide innovative solutions for every need, } \\
\text { combine ideas, extract original ideas, absorb new ideas or strategies, gather ideas, select useful } \\
\text { ideas, acquire innovative ideas through strategies, compare ideas, weigh ideas, compare ideas, } \\
\text { select operating ideas, find ideas, look for ideas, audit ideas, extract innovations }\end{array}$ & Idea discovery & $\begin{array}{c}\text { M1, M2, } \\
\text { M3, M4, } \\
\text { M6, M9, } \\
\text { M10, M11, } \\
\text { M13, M14 }\end{array}$ & 10 \\
\hline $\begin{array}{l}\text { Implement ideas in a small area, implement idea on a small scale, implement ideas } \\
\text { experimentally, implement innovation in a small framework, implement innovation in a small time } \\
\text { period, implement innovation in a small portion of educational services, solve problems in the } \\
\text { initial implementation, monitor and solve problems in initial implementation, test applicability of } \\
\text { ideas, implement the project in a miniaturized form, implement in a small part, pilot } \\
\text { implementation, implement innovation in a small version }\end{array}$ & $\begin{array}{c}\text { Pilot } \\
\text { implementation of } \\
\text { innovation }\end{array}$ & $\begin{array}{l}\text { M1, M2, } \\
\text { M3, M4, } \\
\text { M6, M9, } \\
\text { M10, M12, } \\
\text { M13, M15 }\end{array}$ & 10 \\
\hline $\begin{array}{l}\text { Implement idea in a wider area, implement the processed idea, provide innovative services in } \\
\text { educational institutions, deliver new services to consumers, market-make innovative idea in } \\
\text { services, provide comprehensive plan of action, provide strategic plan, launch to market, deliver } \\
\text { innovation to market, commercialize, do final implementation, commercialize innovation, provide } \\
\text { higher education market with innovation, deliver innovation to educational community, provide } \\
\text { innovative services to students and industry and services, sell innovation in higher education } \\
\text { market, provide services to higher education market }\end{array}$ & $\begin{array}{c}\text { Innovation } \\
\text { commercialization }\end{array}$ & $\begin{array}{c}\text { M1, M2, } \\
\text { M3, M4, } \\
\text { M6, M9, } \\
\text { M10, M12, } \\
\text { M13 }\end{array}$ & 9 \\
\hline $\begin{array}{l}\text { Evaluate strengths and weaknesses of ideas, refine ideas, analyze innovative thinking, research } \\
\text { on ideas, select practical ideas, analyze ideas, analyze innovative ideas, screen innovative ideas, } \\
\text { evaluate innovative ideas by forming think tanks, criticize innovative ideas, select ideas, evaluate } \\
\text { ideas, screen ideas, measure applicability of ideas, evaluate ideas economically, determine cost } \\
\text { and benefit of ideas, determine feasibility of innovation, suggest innovative strategies to evaluate } \\
\text { ideas }\end{array}$ & Idea selection & $\begin{array}{l}\text { M1, M2, } \\
\text { M3, M4, } \\
\text { M5, M10, } \\
\text { M13, M15 }\end{array}$ & 8 \\
\hline
\end{tabular}

The fifth question measured the resources required for realization of innovation. Table 6 shows that financial resources, technology, human resources, infrastructure and information resources are the main resources to achieve innovation excellence in non-governmental higher education institutions. Frequency of these component was higher than 5.

\section{Table 6 - The resources identified for realization of service innovation excellence}

\begin{tabular}{|c|c|c|c|}
\hline Codes (identified concepts) & Theme & Experts & Frequency \\
\hline $\begin{array}{l}\text { Video projectors, ICT infrastructure, high quality websites, internet, good electronic platform, good } \\
\text { bandwidth, sufficient number of computer sites, up to date and good computers for students, hardware, } \\
\text { software, ERP system, communications, IT in all fields, Web 2, information and communication } \\
\text { technologies, comprehensive management system for processes of a university, modern computer } \\
\text { systems, technological equipment, skilled human resources, social media, e-forums, new updated web sites }\end{array}$ & Technology & $\begin{array}{l}\text { M1, M2, M3, } \\
\text { M4, M5, M6, } \\
\text { M7, M8, } \\
\text { M10, M12, } \\
\text { M13, M14 }\end{array}$ & 12 \\
\hline
\end{tabular}


Table 6 (continued)

\begin{tabular}{|c|c|c|c|}
\hline Codes (identified concepts) & Theme & Experts & Frequency \\
\hline $\begin{array}{l}\text { Knowledge resources, subscription in databases, equipped library, knowledge resources, information } \\
\text { resources, good resources of information and easy access to these resources, access to databases, library, } \\
\text { access to databases, intellectual resources, access to information resources in the world, equipped library }\end{array}$ & $\begin{array}{l}\text { Information } \\
\text { resources }\end{array}$ & $\begin{array}{c}\text { M3, M4, M6, } \\
\text { M7, M8, M9, } \\
\text { M12, M13 }\end{array}$ & 8 \\
\hline $\begin{array}{l}\text { Physical resources, hardware resources, laboratories, workshops, class equipment, facilities of physical } \\
\text { space, human resources, good physical space, useful teaching space, useful learning environment, science } \\
\text { and technology parks, innovation laboratories, Start Up, suitable campus, workshops, laboratories }\end{array}$ & Infrastructure & $\begin{array}{c}\text { M3, M4, M7, } \\
\text { M8, M9, } \\
\text { M12, M14 }\end{array}$ & 7 \\
\hline $\begin{array}{l}\text { Human resources, professors, talented students, managerial resource, faculty members, elite faculty } \\
\text { members interested in innovation, innovative teachers, dynamic and creative professors, talented students, } \\
\text { elite professors, elite students, elite and talented members, faculty members specializing in teaching and } \\
\text { research, technical personnel, technologically skilled human resources }\end{array}$ & $\begin{array}{l}\text { Human } \\
\text { resources }\end{array}$ & $\begin{array}{c}\text { M2, M4, M7, } \\
\mathrm{M} 10, \mathrm{M} 12 \\
\mathrm{M} 13\end{array}$ & 6 \\
\hline $\begin{array}{l}\text { Financial resources, governmental financial resources, monetary and financial resource allocation, budget } \\
\text { funding, sponsorship }\end{array}$ & $\begin{array}{l}\text { Financial } \\
\text { resources }\end{array}$ & $\begin{array}{c}\mathrm{M} 1, \mathrm{M} 2, \mathrm{M} 9 \\
\mathrm{M} 10, \mathrm{M} 13\end{array}$ & 5 \\
\hline
\end{tabular}

Development of the conceptual model. As noted earlier, literature was reviewed to extract basic indicators and design interview questions which were provided to 15 experts. Semi-structured interviews and analysis of the findings showed that several indicators were extracted in five themes including innovation leadership, innovation strategies, process innovation, innovation resources, competencies and capabilities of faculty members and employees. Sub-themes were identified for each of these five themes. Innovation vision, professional competency, innovation culture, motivation, commitment to innovation and market orientation were identified for innovation leadership. The most important strategies identified for achieving innovation in higher education institutions included innovation creation, benchmarking, expert recruitment, joint venture and innovation absorption. In addition, task competency, learning ability, research skills, innovation intention, information literacy, creative thinking and teamwork skills are the most important competencies and capabilities identified for realization of innovation in higher education institutions. Market evaluation, idea exploration, idea selection, innovative planning, pilot implementation, commercialization and feedback are the major processes required for realization of innovation in non-governmental higher education institutions. The resources required for realization of innovation included financial resources, technology, human resources, infrastructure and informational resources. Therefore, 5 themes and 30 sub-themes were identified for realization of innovation excellence in non-governmental higher education institutions by reviewing literature and interviewing with 15 experts. This paves the way for innovation excellence in services provided by non-governmental higher education. The conceptual model based on five themes and 30 subthemes is shown in Figure 2.

Discussion and conclusion. To identify indicators of service innovation excellence in nongovernmental higher education institutions, theoretical background of innovation, innovation excellence, educational services, educational service innovation and service innovation excellence of institutions was reviewed through a preliminary study. At this phase, literature was reviewed to develop the primary model which was then presented to experts. At this phase, 15 experts and directors of non-governmental universities were selected and interviewed by a semi-structured technique. Then, the interviews were transcribed verbatim and analyzed. Primary and secondary coding was performed; finally, themes were identified. As shown in semi-structured interviews and analysis of their findings, several indicators were extracted in five themes including innovation leadership, innovation strategies, innovation process, innovation resources, competencies and capabilities of faculty members and employees. Subthemes were identified for these themes. Subthemes of innovation leadership include innovation vision, professional competencies, innovation culture, motivation, commitment to innovation and market orientation. These subthemes show that leadership of a higher education institution primarily requires an innovation vision to realize service innovation excellence and make people commit to its realization. However, the leadership requires professional competencies to do this. It is vitally important to establish 
a culture for institutionalizing innovation. This culture will provide the context for encouraging innovation. Market orientation suggests that leaders must have the ability to identify market requirements. This as well as services tailored to the needs of market are characteristics of leadership to realize innovation.

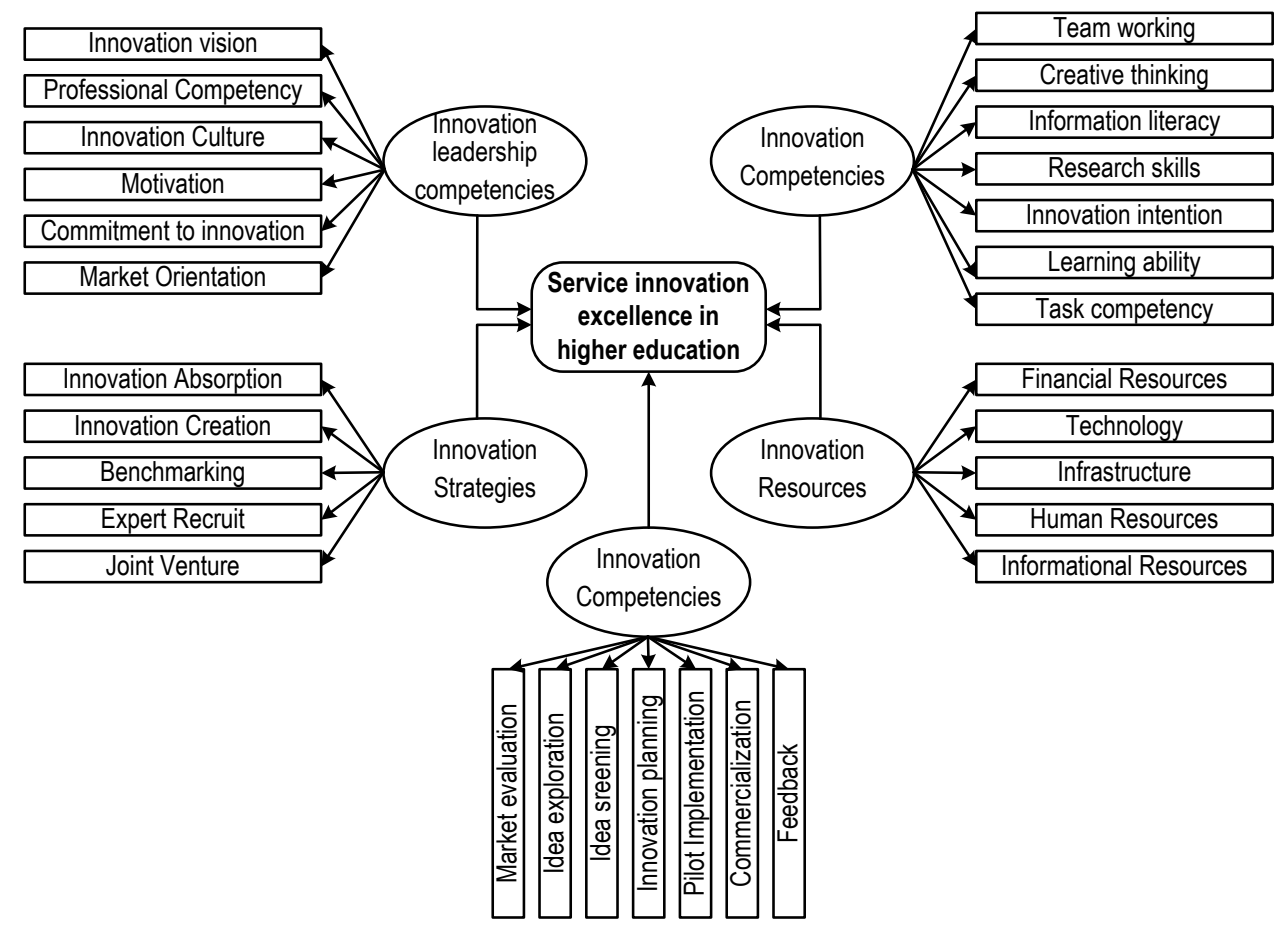

Figure 2 - Components of service innovation excellence in higher education.

According to Maritz et al [22] innovative leaders authorize members to act independently and try new ideas. In addition, innovation leadership can challenge thoughts and ideas of employees by stimulating followers and promote innovation and creativity among them [23]. Gong et al [24] believe that innovation leadership promotes and encourages innovative behaviors in the organization and this type of leadership set common goals and allows leaders to stimulate members to search for new working processes. Leadership is one of the main factors in guiding the organization to absorb knowledge and learning capabilities. Leadership plays a critical role in motivating and guiding the organization to attract internal and external knowledge and improve learning capabilities [25].On the other hand, innovation leadership provides a creative environment using processes such as questioning current processes, stimulating followers to challenge previous presumptions and presenting new operating processes in order to encourage innovation and guide organizational innovations [26].

Findings show that the most important strategies for achieving innovation in higher education institutions include innovation creation, benchmarking, expert recruitment, joint venture and innovation absorption. Task competency, learning ability, research skills, innovation intention, information literacy, creative thinking and teamwork skills are the most important competencies and capabilities identified for realization of innovation in higher education institutions. Market evaluation, idea exploration, idea selection, innovative planning, pilot implementation, commercialization and feedback are the major 
processes required for realization of innovation in non-governmental higher education institutions. The resources required for realization of innovation included financial resources, technology, human resources, infrastructure and informational resources. Therefore, 5 themes and 30 sub-themes were identified for realization of innovation excellence in non-governmental higher education institutions by reviewing literature and interviewing with 15 experts. This paves the way for innovation excellence in services provided by non-governmental higher education.

Managerial implications. Despite the importance of innovation in organizations and popularity of this concept in organizational management literature, there is a theoretical gap in higher education institutions. The model developed for innovation excellence fills this theoretical gap. This model provides a map for higher education managers to determine competencies of leadership and faculty members by identified themes and provide the strategies required for innovation. Innovation process helps higher education managers to take steps for creating an innovation scientifically and avoid unnecessary actions and costs. The resources required to realize innovations, as identified in the conceptual model, helps managers to provide the resources beforehand and avoid failure. Service innovation excellence model used in non-governmental higher education institutions can provide an opportunity for management of these institutions to implement innovation properly by adopting scientific strategies and processes. This model can prevent trials and errors which may cause considerable costs for these institutions. By developing service innovation excellence in non-governmental higher education institutions, this model can be a guidance for these institutions to attend higher education market and gain competitive advantage.

Acknowledgement. The authors are grateful for the valuable comments and suggestion from the respected reviewers. Their valuable comments and suggestions have enhanced the strength and significance of our paper.

1. Ettlie, J., \& Rosenthal, S. (2011). Service versus Manufacturing Innovation. Journal of Product Innovation Management, 28 (2), 285-299

2. Vincent-Lancrin, S. (2014). Overview: Why and how to measure innovation in education. Educational Research and Innovation, 19-38.

3. Yongming, Z. (2013). The Exploration of the Subjective-Involved Standard of the Educational Innovation. Journal of Ankang University, 3 (1), $29-42$.

4. Archer, W., Garrison, R., \& Anderson, T. (2013).Adopting disruptive technologies in traditional universities: Continuing education as an incubator for innovation. Canadian Journal of University Continuing Education, 25 (1), $452-472$.

5. Popescu, M., \& Crenicean, L.C. (2012). Innovation and Change in Education-Economic Growth Goal in Romania in the Context of Knowledge-Based Economy. Procedia-Social and Behavioral Sciences, 46 (2), 3982-3988.

6. Knight, J. (2011). Education hubs: a fad, a brand, an innovation? Joumal of Studies in International Education, 15 (3), 221-240.

7. Leadbeater, C. (2012). Innovation in education: Lessons from pioneers around the world. Bloomsbury Qatar Foundation Publishing.

8. Chen, J.S., Tsou, H.T., \& Ching, R.K. (2011). Co-production and its effects on service innovation.Industrial Marketing Management, 40 (8), 1331-1346.

9. Chen, W.J. (2011).Innovation in hotel services: culture and personality. International Journal of Hospitality Management, 30, 64-72.

10. Toivonen, M., Tuominen, T. (2006). Emergence of Innovations in Services: Theoretical discussion and two case studies. Proceedings from International ProACT Conference: IInnovation Pressure Rethinking Competitiveness, Policy and the Society in a Global Economy. Tampere, Finland.

11. Zhou, K.Z., \& Li, C.B. (2012). How knowledge affects radical innovation: Knowledge base, market knowledge acquisition, and internal knowledge sharing. Strategic Management Journal, 33 (9), 1090-1102.

12. Froehle, C.M., Roth, A.V., Chase, R.B., \& Voss, C.A. (2000). Antecedents of New Service Development Effectiveness: An Exploratory Examination of Strategic Operations Choices. Journal of Service Research, 3 (1), 3-17.

13. Tsou, H. (2012). Collaboration competency and partner match for e-service product innovation through knowledge integration mechanisms. Journal of Service Management, 23 (5), 640-663.

14. Hertog D., (2010). Is there a Rationale for Services R\&D and Innovation Policies? International Journal of Services Technology and Management, 9, 334-354. 
15. Park, S.M., \& Dahlgaard, J.J. (2008). A strategy for building sustainable innovation excellence-a Danish study. Corporate sustainability as a challenge for comprehensive management. Physica-Verlag HD, 77-94.

16. Dervitsiotis, K.N. (2010). A framework for the assessment of an organisation's innovation excellence. Total Quality Management, 21 (9), 903-918.

17. Lin, R. (2009). Designing friendship into modern products. Friendships: Types, cultural, psychological and social, 1-24.

18. Asif, M., \& Gouthier, M.H. (2014). What service excellence can learn from business excellence models. Total Quality Management \& Business Excellence, 25 (5-6), 511-531.

19. Sandelowski, M. (2015). A matter of taste: evaluating the quality of qualitative research. Nursing inquiry, 22 (2), 86-94.

20. Rowlands, T., Waddell, N., \& McKenna, B. (2016). Are We There Yet? A Technique to Determine Theoretical Saturation. Journal of Computer Information Systems, 56 (1), 40-47.

21. Malterud, K., Siersma, V.D., \& Guassora, A.D. (2015). Sample Size in Qualitative Interview Studies Guided by Information Power. Qualitative health research, 1049732315617444.

22. Maritz, A., de Waal, A., Buse, S., Herstatt, C., Lassen, A., \& Maclachlan, R. (2014). Innovation education programs: toward a conceptual framework. European Journal of Innovation Management, 17 (2), 166-182.

23. García-Morales, V.J., Lloréns-Montes, F.J., \& Verdú-Jover, A.J. (2008). The effects of transformational leadership on organizational performance through knowledge and innovation. British journal of management, 19 (4), 299-319.

24. Gong, Y., Huang, J.C., \& Farh, J.L. (2009). Employee learning orientation, transformational leadership, and employee creativity: The mediating role of employee creative self-efficacy. Academy of management Journal, 52 (4), 765-778.

25. Hoon Song, J., Kolb, J.A., Hee Lee, U., \& Kyoung Kim, H. (2012). Role of transformational leadership in effective organizational knowledge creation practices: Mediating effects of employees' work engagement. Human Resource Development Quarterly, 23 (1), 65-101.

26. Aarons, G.A., \& Sommerfeld, D.H. (2012). Leadership, innovation climate, and attitudes toward evidence-based practice during a statewide implementation. Journal of the American Academy of Child \& Adolescent Psychiatry, 51 (4), 423-431.

A. Норузі, здобувач кафедри управління освітою, Тегеранський університет (м. Тегеран, Іран);

$\boldsymbol{X}$. Aбілі, PhD, професор кафедри управління освітою, Тегеранський університет (м. Тегеран, Іран);

Д. Пуркарімі, PhD, асистент кафедри управління освітою, Тегеранський університет (м. Тегеран, Іран);

M. Ансарі, PhD, доцент кафедри MBA, Тегеранський університет (м. Тегеран, Іран)

Концептуальна модель інноваційного удосконалення сфери послуг для неурядової вищої освіти

Використовуючи якісний метод, у статті розроблена модель інноваційного удосконалення в сфері послуг для недержавної вищої освіти. Аналіз якісних даних показав, що п'ять основних напрямків, включаючи інноваційне лідерство, інноваційні стратегії, інноваційний процес, інноваційні ресурси, компетенції та можливості викладачів, формують інноваційне удосконалення недержавної вищої освіти. Найбільш важливі стратегії, які були визначені для досягнення інновацій у вищих навчальних закладах, включають створення інновацій, порівняльний аналіз, підбір експертів, спільне підприємство та інноваційне поглинання. Крім того, компетенція завдання, здатність до навчання, дослідницькі навички, прагнення до інновацій, інформаційна грамотність, творче мислення і навички командної роботи є найбільш важливими компетенціями і можливостями, виявленими для реалізації інновацій у вищих навчальних закладах.

Ключові слова: інновація, послуги, модель удосконалення, вища освіта, модель.

A. Норузи, соискатель кафедры управления образованием, Тегеранский университет (г. Тегеран, Иран);

X. Aбили, PhD, профессор кафедры управления образованием, Тегеранский университет (г. Тегеран, Иран);

Д. Пуркарими, PhD, ассистент кафедры управления образованием, Тегеранский университет (г. Тегеран, Иран);

M. Ансари, PhD, доцент кафедры MBA, Тегеранский университет (г. Тегеран, Иран)

Концептуальная модель инновационного усовершенствования сферы услуг для неправительственного высшего образования

Используя качественный метод, в статье разработана модель инновационного усовершенствования в сфрере услуг для негосударственного высшего образования. Анализ качественных данных показал, что пять основных направлений, включая инновационное лидерство, инновационные стратегии, инновационный процесс, инновационные ресурсы, компетенции и возможности преподавателей, формируют инновационное усовершенствование негосударственного высшего образования. Наиболее важные стратегии, которые были определены для достижения инноваций в высших учебных заведениях, включают создание инноваций, сравнительный анализ, подбор экспертов, совместное предприятие и инновационное поглощение. Кроме того, компетенция задачи, способность к обучению, исследовательские навыки, стремление к инновациям, информационная грамотность, творческое мышление и навыки командной работы являются наиболее важными компетенциями и возможностями, выявленными для реализации инноваций в высших учебных заведениях.

Ключевые слова: инновация, услуги, модель усовершенствования, высшее образование, модель.

Отримано 31.10.2016 p. 